\title{
Intra-articular injections with corticosteroids and sodium hyaluronate for treating temporomandibular joint disorders: A systematic review
}

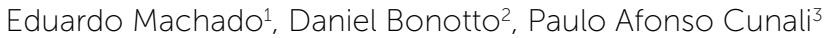

\begin{abstract}
Introduction: In some cases, conservative treatment of internal derangements of the Temporomandibular Joint (TMJ) is considered little responsive. Thus, it is necessary to accomplish treatments that aim at reducing pain and improve patients' functions who present arthrogenic temporomandibular disorders. Objective: This study, by means of a systematic review of the literature, aimed to analyze the effectiveness of intra-articular injections with corticosteroids and sodium hyaluronate for treating internal derangements of the TMJ. Methods: Carry out a research in the following databases: MEDLINE, Cochrane, EMBASE, Pubmed, Lilacs, and BBO, considering publications issued between 1966 and October of 2010, focusing on randomized or quasi-randomized controlled clinical trials, single or double-blind. Results: After applying the inclusion criteria we collected 9 articles, 7 of which were randomized controlled double-blind clinical trials and 2 randomized controlled single-blind clinical trials. Conclusion: After analyzing the literature, it was found that intra-articular injection with corticosteroids and sodium hyaluronate seems to be an effective method for treating internal derangements of the TMJ. However, further randomized controlled clinical trials, with representative samples and longer follow-up time must be carried out in order to assess the real effectiveness of this technique.
\end{abstract}

Keywords: Corticosteroids. Sodium hyaluronate. Temporomandibular joint. Temporomandibular joint dysfunction syndrome. Temporomandibular joint disorders.

Introdução: em algumas situações, o tratamento conservador das alterações internas da articulação temporomandibular apresenta-se pouco responsivo. Nessas condições, torna-se necessária a realização de tratamentos que visem reduzir a dor e melhorar a função dos pacientes frente a disfunções temporomandibulares articulares. Objetivo: esse trabalho, por meio de uma revisão sistemática de literatura, teve como objetivo analisar a efetividade de infiltrações intra-articulares com corticosteroides e com hialuronato de sódio no tratamento para as alterações internas da ATM. Métodos: foi feito levantamento nas bases de pesquisa MEDLINE, Cochrane, EMBASE, PubMed, Lilacs e BBO, abrangendo os anos de 1966 a outubro de 2010, com enfoque em estudos clínicos controlados randomizados ou quase-randomizados, cegos ou duplo-cegos. Resultados: após a aplicação dos critérios de inclusão, chegou-se a nove artigos, sendo que sete eram estudos clínicos controlados randomizados duplo-cego e dois eram estudos clínicos controlados randomizados apenas cegos. Conclusões: pela análise da literatura, verifica-se que a infiltração intra-articular com corticosteroides e hialuronato de sódio parece ser um método efetivo no tratamento das alterações internas da ATM. Porém, são necessários mais estudos clínicos controlados randomizados, com amostras representativas e tempo de acompanhamento longo, para avaliar a real efetividade da técnica.

Palavras-chave: Corticosteroides. Ácido hialurônico. Articulação temporomandibular. Síndrome da disfunção da articulação temporomandibular. Transtornos da articulação temporomandibular.

${ }^{1}$ Specialist in Temporomandibular Disorders (TMD) and Orofacial pain, Federal University of Paraná (UFPR).

${ }^{2} \mathrm{MSc}$ in Health Sciences, Pontifical Catholic University of Paraná (PUC-PR) Professor, Graduation Program in TMD and Orofacial pain, UFPR. ${ }^{3} \mathrm{PhD}$ in Sciences, Federal University of Sao Paulo (UNIFESP). Professor, Graduation and Post-Graduation Programs in Dentistry, UFPR.

Submitted: November 23, 2011 - Revised and accepted: February 20, 2012
How to cite this article: Machado E, Bonotto D, Cunali PA. Intra-articular injections with corticosteroids and sodium hyaluronate for treating temporomandibular joint disorders: A systematic review. Dental Press J Orthod. 2013 SeptOct;18(5):128-33.

" The authors report no commercial, proprietary or financial interest in the products or companies described in this article.

Contact address: Eduardo Machado

Rua Francisco Trevisan, 20 - Santa Maria/RS - Brazil

CEP: 97050-230 - E-mail: dr.eduardomachado@yahoo.com.br 


\section{INTRODUCTION}

The condyle/articular disc complex incoordination is among the temporomandibular joint disorders. It results from the collapse regarding the normal function of the disc on the condyle and it is due to disc collateral ligaments incompetence and lower retrodiscal plate. Examples of this case are disc displacements with and without reduction which may be associated with inflammatory changes such as capsulitis, synovitis and retrodiscitis or with degenerative changes such as osteoarthritis and osteoarthrosis of the Temporomandibular Joint (TMJ). ${ }^{1}$

The protocols for initial treatment consists of choosing reversible and little invasive therapies, such as occlusal splints, non-steroidal anti-inflammatory drugs (NSAID), analgesics, physiotherapy, thermotherapy, microcurrent, functional repose and patient advice. However, in some cases, conservative treatment becomes little responsive due to current structural changes. ${ }^{1}$ Thus, more complex procedures such as intra-articular injections with corticosteroids or sodium hyaluronate, arthrocentesis, arthroscopy or open surgery for TMJ appear as therapeutic options to control and treat TMJ internal derangements.

In such cases, intra-articular injections with corticosteroids and sodium hyaluronate - the hyaluronic acid sodium salt, a clinical procedure known as viscosupplementation - appear as an alternative of a treatment that is less invasive than surgical procedures for TMJ. Thus, this study aimed at analyzing, through a systematic literature review and within the context of an evidence-based Dentistry, the effectiveness of intra-articular injections with corticosteroids and sodium hyaluronate as a treatment for TMJ internal derangements.

\section{MATERIAL AND METHODS}

We carried out a computerized research in the following databases: MEDLINE, Cochrane, EMBASE, Pubmed, Lilacs and BBO, considering publications issued between 1966 and October of 2010. The research descriptors comprised terms widely used within the line of research proposed by this study. The research descriptors used were "corticosteroids", "hyaluronic acid", "sodium hyaluronate", "temporomandibular disorder," "temporomandibular joint", "craniomandibular disorder", "tmd", "tmj", "osteoarthritis" and "osteoarthrosis", which were crossed in search engines. The initial list of articles, evaluated by their title and abstract, was submitted to review carried out by two appraisers who applied inclusion criteria hereinbelow to determine the final sample of articles. Should there have been any discrepancy between the results obtained by the reviewers, a third appraiser would be consulted and requested to read the full version of the article.

The inclusion criteria for selecting the articles were:

"Studies involving human subjects in which the effectiveness of TMJ intra-articular injections with corticosteroids and/or sodium hyaluronate $(\mathrm{SH})$ in the treatment of temporomandibular joint disorders was evaluated.

"Studies in which corticosteroids and/or SH were compared to placebo or combined with other therapies such as arthrocentesis or arthroscopy.

"Diagnostic criteria for TMDs based on clinical examinations and/or computed tomography (CT) or nuclear magnetic resonance images (MRI).

"We included randomized controlled clinical trials (RCTs) or quasi-randomized, single or double-blind trials, only.

" No language restriction concerning publications issued between 1966 and October of 2010.

\section{RESULTS}

The initial list of articles comprised 412 possible studies. After applying the inclusion criteria, we obtained 9 randomized controlled clinical trials, 7 of which were double-blind and 2 single-blind, as shown in Figure 1.

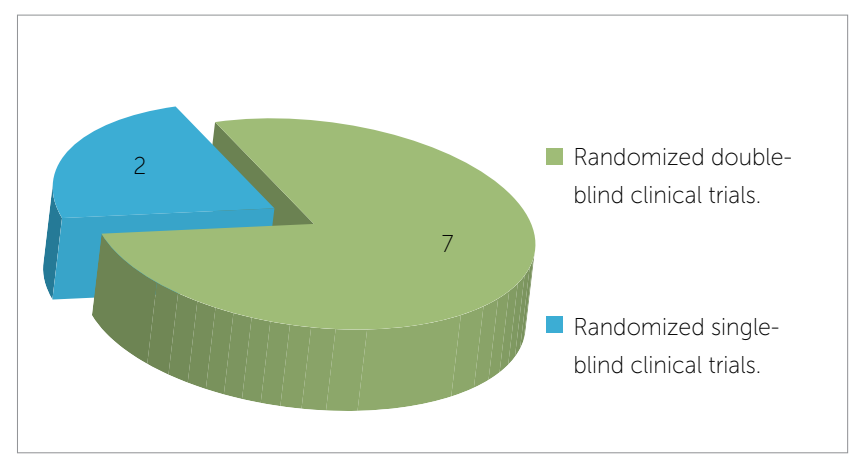

Figure 1 - Selected studies design 
Table 1 - Studies included in the research and which compare corticosteroids, sodium hyaluronate, and placebo.

\begin{tabular}{|c|c|c|c|c|c|}
\hline $\begin{array}{c}\text { Authors and year of } \\
\text { publication }\end{array}$ & Study design & $\begin{array}{l}\text { Criteria for TMD } \\
\text { diagnosis }\end{array}$ & Final sample size (n) & $\begin{array}{l}\text { Evaluation } \\
\text { period }\end{array}$ & Results \\
\hline $\begin{array}{c}\text { Kopp et al² } \\
1985\end{array}$ & $\begin{array}{l}\text { Double-blind, controlled } \\
\text { RCT }\end{array}$ & $\begin{array}{l}\text { Helkimolndex, pain, } \\
\text { mandibular function and } \\
\text { joint sounds }\end{array}$ & $\begin{array}{c}18 \text { tt SH} \\
15 \text { tt CO (Beta-methasone) }\end{array}$ & 4 weeks & $\begin{array}{l}\text { Both groups had pain } \\
\text { reduced. No statistical } \\
\text { differences between } \\
\text { groups. }\end{array}$ \\
\hline $\begin{array}{c}\text { Kopp et } \mathrm{al}^{3} \\
1991\end{array}$ & $\begin{array}{l}\text { Double-blind, controlled } \\
\text { RCT. }\end{array}$ & $\begin{array}{l}\text { Patients with rheumatoid } \\
\text { arthritis and TMJ internal } \\
\text { derangements }\end{array}$ & $\begin{array}{c}14 \text { tt SH } \\
14 \text { tt CO (Methyl- } \\
\text { prednisolone) } \\
13 \text { tt SS (placebo) }\end{array}$ & 4 weeks & $\begin{array}{l}\text { Improvements in the } 3 \\
\text { groups with } \mathrm{SH} \text { and } \mathrm{CO} \\
\text { showing the best results. }\end{array}$ \\
\hline $\begin{array}{l}\text { Bertolami et al }{ }^{4} \\
1993\end{array}$ & $\begin{array}{l}\text { Double-blind, controlled } \\
\text { RCT. }\end{array}$ & $\begin{array}{l}\text { Helkimo } \\
\text { Index }\end{array}$ & $\begin{array}{c}80 \text { tt SH } \\
41 \text { tt SS (placebo) }\end{array}$ & 6 months & $\begin{array}{l}\text { SH: significant improvement } \\
\text { in patients with DDWR. }\end{array}$ \\
\hline $\begin{array}{l}\text { Hepguler et al }{ }^{5} \\
2002\end{array}$ & $\begin{array}{l}\text { Double-blind, controlled } \\
\text { RCT. }\end{array}$ & $\begin{array}{c}\text { Helkimo } \\
\text { Index modified }\end{array}$ & $\begin{array}{c}19 \text { tt SH } \\
19 \text { tt SS (placebo) }\end{array}$ & 6 months & $\begin{array}{c}\text { SH: effective in DDWR } \\
\text { cases. }\end{array}$ \\
\hline $\begin{array}{l}\text { Shi et } \mathrm{al}^{6} \\
2002\end{array}$ & $\begin{array}{l}\text { Double-blind, controlled } \\
\text { RCT. }\end{array}$ & $\begin{array}{c}\text { Articular pain and } \\
\text { tenderness, jaw function } \\
\text { and TMJ sounds. }\end{array}$ & $\begin{array}{c}35 \text { tt SH } \\
28 \text { tt CO (Prednisolone) }\end{array}$ & 4-5 weeks & $\begin{array}{l}\text { SH and CO groups: } \\
\text { improvements related } \\
\text { to pain and function. } \\
\text { No statistical differences } \\
\text { between groups. }\end{array}$ \\
\hline $\begin{array}{l}\text { Bjørnland et al } \\
2007\end{array}$ & $\begin{array}{l}\text { Double-blind, controlled } \\
\text { RCT. }\end{array}$ & $\begin{array}{l}\text { RDC: TMJ osteoarthritis } \\
\text { and myofascial pain. }\end{array}$ & $\begin{array}{c}20 \text { tt SH } \\
20 \text { tt CO (Celestone) }\end{array}$ & 6 months & $\begin{array}{l}\text { Both groups had pain } \\
\text { reduced, but SH was more } \\
\text { effective. }\end{array}$ \\
\hline $\begin{array}{l}\text { Møystad et } a l^{8} \\
2008\end{array}$ & $\begin{array}{l}\text { Double-blind, controlled } \\
\text { RCT. }\end{array}$ & $\begin{array}{l}\text { RDC: TMJ osteoarthritis } \\
\text { and CT examination. }\end{array}$ & $\begin{array}{c}17 \text { tt SH } \\
19 \text { tt CO (Celestone) }\end{array}$ & 6 months & $\begin{array}{c}\text { Progression, regression and } \\
\text { absence of changes were } \\
\text { identified in treated and } \\
\text { untreated TMJs. }\end{array}$ \\
\hline
\end{tabular}

RCT: randomized clinical trial; tt: treatment; SH: sodium hyaluronate; CO: corticosteroids; SS: saline solution; DDWR: disc displacement with reduction.

Table 2 - Studies included in the research and which compare arthrocentesis or arthroscopic followed or not by injection with corticosteroid and/or sodium hyaluronate.

\begin{tabular}{|c|c|c|c|c|c|}
\hline $\begin{array}{c}\text { Authors and year of } \\
\text { publication }\end{array}$ & Study design & $\begin{array}{l}\text { Criteria for TMD } \\
\text { diagnosis }\end{array}$ & Final sample size (n) & Evaluation period & Results \\
\hline $\begin{array}{c}\text { McCain et } \mathrm{al}^{9} \\
1989\end{array}$ & $\begin{array}{c}\text { Single-blind, controlled } \\
\text { RCT. }\end{array}$ & $\begin{array}{l}\text { Pain, tenderness and } \\
\text { joint sounds }\end{array}$ & $\begin{array}{l}\text { 33 TMJs: arthroscopy + RL } \\
+\quad+S H \\
22 \text { TMJs: arthroscopy + RL }\end{array}$ & 8 weeks & $\begin{array}{c}\text { No statistically } \\
\text { significant differences } \\
\text { between groups. }\end{array}$ \\
\hline $\begin{array}{l}\text { Alpaslan et a }\left.\right|^{10} \\
2001\end{array}$ & $\begin{array}{c}\text { Single-blind, controlled } \\
\text { RCT. }\end{array}$ & $\begin{array}{l}\text { Pain, limited mouth } \\
\text { opening, sounds and } \\
\text { radiographic evaluation }\end{array}$ & $\begin{array}{l}26 \text { TMJs: arthrocentesis + SH } \\
19 \text { TMJs: arthrocentesis + SS }\end{array}$ & 24 months & $\begin{array}{c}\text { Arthrocentesis with } \mathrm{SH} \text { : } \\
\text { superior effects than } \\
\text { without } \mathrm{SH} \text {. }\end{array}$ \\
\hline
\end{tabular}

RCT: randomized clinical trial; RL: ringer lactate, SH: sodium hyaluronate; SS: saline solution.

Kappa coefficient between reviewers was of 1.00 and the results of the selected studies are presented in Tables 1 and 2.

\section{DISCUSSION}

The qualification of the generated scientific evidence is related to the methodological criteria and the designs adopted by the authors in the clinical studies. Thus, criteria such as randomization, blinding, sam- ple size calculation, calibration, control of involved factors, among others, aimed at making scientific evidence more precise and reliable and this information should be provided in order to facilitate readers' appreciation and discussion of the scientific article. ${ }^{11,12}$ Furthermore, knowledge about the study designs which generate the highest levels of evidence must be of common knowledge: meta-analysis, systematic reviews and randomized clinical trials. 
Hyaluronic acid (HA) is a mucopolysaccharide acid present in ground substance animal tissues. It is the major component of the synovial fluid and has an important role in lubrication, nutrition, homeostasis and load absorption of articular tissues. ${ }^{13,14,15}$ In cases of inflammatory and degenerative changes of joints, the concentration and molecular weight of HA id reduced. ${ }^{16,17}$ Viscosupplementation with sodium hyaluronate increases the concentration and molecular weight of HA in the synovial fluid, ${ }^{18}$ restoring tissues lubrication and nutrition as well as minimizing mechanic stress. ${ }^{15,19}$ Moreover, intra-articular SH injection presents an analgesic effect by blocking receptors and endogenous substances that cause pain in synovial tissues. In addition, it promotes a release of adhesion areas between the articular disc and the mandibular fossa, increasing joint mobility and allowing better synovial fluid circulation. ${ }^{19}$

At first, the intra-articular sodium hyaluronate injection was used in race horses with traumatic arthritis. ${ }^{20}$ Afterward, it was based on studies on the osteoarthritis model, induced in animals, and combined with the inhibition of osteoarthritis development. ${ }^{21}$ In the mid-70's, viscosupplementation with sodium hyaluronate began to be used in humans for osteoarthritis treatment of large joints such as knee, hip and shoulder, ${ }^{22}$ being indicated for the internal derangements of TMJ after 1979. ${ }^{23}$

Glucocorticoids are yet the most effective anti-inflammatory drugs available, promoting symptomatic improvements of a series of clinical manifestations. However, they present risks of potential adverse effects which affect several organs depending on the dosage and, mainly, the duration of the treatment. For short periods (up to two weeks), even at high doses, the probability of causing adverse side effects is low. In long-term treatments, serious side effects appear, limiting the effectiveness of glucocorticoids in chronic diseases. Glucocorticoids have a very original mechanism of action, essentially genomic (transcriptional) and characterized by the activation (transactivation) or inhibition (transrepression) of numerous target genes. These molecules act in many cells, including not only innate immunity cells (macrophages, granulocytes, mast cells) and adaptive immunity cells (lymphocytes), but also other cells (fibroblasts, epithelial and endothelial cells). ${ }^{24}$
The results of this systematic review show that many of the selected studies had small samples and short follow-up periods. In addition, the results highlight the absence of a universal and standardized method for diagnosing TMD which hampers comparison between clinical trials. In this systematic review, different authors used different indexes for diagnosing TMD: RDC/TMD,${ }^{25}$ Helkimo in$\mathrm{dex},{ }^{26,27}$ adaptations of these or other criteria, highlighting the necessity of further randomized controlled clinical trials using universal, standardized and valid index in representative samples and with a longer follow-up period.

According to the studies included in accordance with the methodological criteria of this systematic review, significant scientific evidence demonstrates that viscosupplementation with sodium hyaluronate is an effective treatment for TMJ internal derangements at short ${ }^{2,3,6}$ and medium ${ }^{4,5,7}$ terms, with results that are similar ${ }^{2,3,6}$ or greater ${ }^{7}$ than the ones obtained by corticosteroids intra-articular injections. Furthermore, combining $\mathrm{SH}$ with arthrocentesis brought major improvements after surgery, greater than those obtained by the group that did not receive $\mathrm{SH} .{ }^{10}$ On the other hand, combining or not $\mathrm{SH}$ with arthroscopy did not show any statistically significant differences. ${ }^{9}$ Some limitations can be associated with some of this evidence: Small samples, ${ }^{2,3}$ short follow-up time $e^{2,3,6,9}$ and lack of information on how many patients were lost or drop-out during the study. ${ }^{4,9,10}$ Such limitations reduce the power of the scientific evidence generated.

Other clinical studies assessing viscosupplementation with sodium hyaluronate, which present good evidence level, but were not included in this systematic review due to some issues concerning the criteria of randomization ${ }^{28}$ or blinding, ${ }^{29,30}$ indicate symptoms reduction and functional improvements in cases with joint TMD, with results that lasted during follow-up. ${ }^{28,29,30}$ Evaluations of SH intra-articular injections protocols showed results statistically equivalent to therapy carried out with occlusal splints for 6 months. $^{28}$

Computed tomography examinations, which proposed to assess changes in osteoarthritic TMJ due to intra-articular injections, show that progression, regression and absence of changes in cases with 
osteoarthritis are observed in TMJ that have been treated and in contralateral TMJ that have not been treated, showing no statistically significant differences between sodium hyaluronate and corticosteroid. ${ }^{8}$ Moreover, they highlight the importance of assessments carried out by imaging examinations associated with clinical criteria in order to analyze the progression or regression of TMJ osteoarthritis.

The accomplishment of further randomized controlled clinical trials, with representative samples and longer follow-up periods, shall enable not only the evaluation concerning the real effectiveness of corticosteroids and sodium hyaluronate, but also the obtainment of an objective protocol for using them. This technique seems to perform well in refractory situations regarding conservative treatments, arthralgias with limitation of movement and/or severe joint sounds, arthralgia associated with moderate and severe degenerative changes and in cases of movement limitation caused by disc displacement without reduction and adhesions.

At first, in cases of temporomandibular disorders, the focus must be noninvasive, conservative and reversible, making use of therapeutics such as occlusal splints, pharmacotherapy, physiotherapy, thermotherapy, microcurrent, functional rest, and patient advice. In those cases in which conservative treatment is not responsive, corticosteroids and sodium hyaluronate intra-articular injections appear as a non-surgical, low invasive and safe alternative which is associated with good results at short and medium terms when treating internal derangements of TMJ.

With regard to the orthodontic specialty, it is important to consider knowledge based on evidence and relative to the action mechanisms and clinical applications of many different therapeutic options for TMD patients, so that the orthodontist and the patient are aware of the therapeutic option regarding the intraarticular injections with corticosteroids and sodium hyaluronate as well as its safety and efficacy in refractory cases concerning conservative treatment.

\section{CONCLUSIONS}

"According to randomized controlled clinical trials, the intra-articular injections with corticosteroids and sodium hyaluronate seem to be an effective method to control TMJ internal derangements at short and medium terms.

" In short-term treatments, the effects of intraarticular injections with sodium hyaluronate are similar to those regarding the injections with corticosteroids, while in long-term treatments, injections with sodium hyaluronate showed better results.

" Further randomized controlled clinical trials with representative samples and long followup times are necessary to assess the real effectiveness of the intra-articular injections with corticosteroid and sodium hyaluronate technique and to establish an objective protocol. 


\section{REFERENCES}

1. Okeson JP. Management of temporomandibular disorders and occlusion. 4th ed. St. Louis: Mosby; 1998

2. Kopp S, Wenneberg B, Haraldson T, Carlsson GE. The short-term effect of intra-articular injections of sodium hyaluronate and corticosteroid on temporomandibular joint pain and dysfunction. J Oral Maxillofac Surg 1985:43(6):429-35

3. Kopp S, Akerman S, Nilner M. Short-term effects of intra-articular sodium hyaluronate, glucocorticoid, and saline injections on rheumatoid arthritis. J Craniomandib Disord. 1991;5(4):231-8.

4. Bertolami CN, Gay T, Clark GT, Rendell J, Shetty V, Liu C, et al. Use of sodium hyaluronate in treating temporomandibular joint disorders: a randomized, double-blind, placebo controlled clinical trial. J Oral Maxillofac Surg. 1993;51(3):232-42

5. Hepguler S, Akkoc YS, Pehlivan M, Ozturk C, Celebi G, Saracoglu A, et al. The efficacy of intra-articular sodium hyaluronate in patients with reducing displaced disc. J Oral Rehabil. 2002;29(1):80-6.

6. Shi ZD, Yang F, He ZX, Shi B, Yang MZ. Comparative study on effects of sodium hyaluronate and prednisolone injections on experimental temporomandibular joint osteoarthritis of rabbits. Zhongguo Xiu Fu Chong Jian Wai Ke Za Zhi. (Chinese Journal of Reparative and Reconstructive Surgery). 2002;16(1): 5-10

7. Bjørnland T, Gjaerum AA, Møystad A. Osteoarthritis of the temporomandibular joint: an evaluation of the effects and complications of corticosteroid injection compared with injection with sodium hyaluronate. J Oral Rehabil. 2007:34(8):583-9

8. Møystad A, Mork-Knutsen BB, Bjørnland T. Injection of sodium hyaluronate compared to a corticosteroid in the treatment of patients with temporomandibular joint osteoarthritis: a CT evaluation. Oral Surg Oral Med Oral Pathol Oral Radiol Endod. 2008:105(2):53-60.

9. McCain JP, Balazs EA, de la Rua H. Preliminary studies on the use of a viscoelastic solution in arthroscopic surgery of the temporomandibular joint. J Oral Maxillofac Surg. 1989;47(11):1161-8

10. Alpaslan GH, Alpaslan C. Efficacy of temporomandibular joint arthrocentesis with and without injection of sodium hyaluronate in treatment of internal derangements. J Oral Maxillofac Surg 2001;59(6):613-8

11. Susin C, Rosing CK. Praticando odontologia baseada em evidências 1a ed. Canoas: ULBRA, 1999

12. Susin C, Rosing CK. A importância do treinamento, reprodutibilidade e calibragem para a qualidade dos estudos. Rev Fac Odontol Porto Alegre. 2000:40(2):3-6.

13. Balazs EA, Denlinger JL. Viscosupplementation: a new concept in the treatment of osteoarthritis. J Rheumatol Suppl. 1993;20(39):3-9.

14. Lehninger A, Nelson A. Princípios de Bioquímica. 3ạ ed. São Paulo: Sarvier; 2002.
15. Nitzan DW, Etsion I. Adhesive force: the underlying cause of the disc anchorage to the fossa and/or eminence in the temporomandibular joint--a new concept. Int J Oral Maxillofac Surg. 2002;31(1):94-9

16. Listrat V, Ayral X, Patarnello F, Bonvarlet JP, Simonnet J, Amor B, et al. Arthroscopic evaluation of potential structure modifying activity of hyaluronan (Hyalgan) in osteoarthritis of the knee. Osteoarthr Cartil. 1997:5(3):153-60.

17. Radin EL, Paul IL. Joint lubrication with artificial lubricants. Arthritis Rheum. 1971;14(1):126-9.

18. Swann DA, Radin El. Role of hyaluronic acid in joint lubrication. Ann Rheum Dis. 1974;33(4):318-26

19. Quinn JN, Bazan NG. Identification of prostaglandin E2 and leukotriene B4 in the synovial fluid of painful, dysfunctional temporomandibular joints. J Oral Maxillofac Surg. 1990;48(9):968-71

20. Rydel NW, Butler J, Balazs EA. Hyaluronic acid in synovial fluid VI. Effect of intra-articular injection of hyaluronic acid on the clinical symptoms of arthritis in track horses. Acta Vet Scand. 1970:11(2):139-55.

21. Xinmin Y, Jian H. Treatment of temporomandibular joint osteoarthritis with viscosupplementation and arthrocentesis on rabbit model. Oral Surg Oral Med Oral Pathol Oral Radiol Endod. 2005;100(3):35-8.

22. Peyron JG, Balazs EA. Preliminary clinical assessment of Na-hyaluronate injection into human arthritic joints. Pathol Biol. 1974;22(8):731-6.

23. Kopp S, Wenneberg B. Effects of occlusal treatment and intraarticular injections on temporomandibular joint pain and dysfunction. Acta Odontol Scand. 1981;39(2):87-96

24. Wannmacher L, Ferreira MBC. Antiinflamatórios esteróides. In: Fuchs D Wannmacher L, editores. Farmacologia Clínica. 2a ed. Rio de Janeiro: Guanabara Koogan; 1998. p. 194-202

25. Dworkin SF, Leresche L. Research diagnostic criteria for temporomandibular disorders: review, criteria, examinations and specifications, critique. J Craniomandib Disord. 1992;6(4):301-55.

26. Helkimo M. Studies on function and dysfunction of the masticatory system. II. Index for anamnestic and clinical dysfunction and occlusal state. Sven Tandlak Tidskr. 1974;67(2):101-21

27. Helkimo M. Studies on function and dysfunction of the masticatory system. III. Analyses of anamnestic and clinical recordings of dysfunction with the aid of indices. Sven Tandlak Tidskr. 1974:67(3):165-81.

28. Guarda-Nardini L, Masiero S, Marioni G. Conservative treatment of temporomandibular joint osteoarthrosis: intra-articular injection of sodium hyaluronate. J Oral Rehabil. 2005:32(10):729-34.

29. Basterzi Y, Sari A, Demirkan F, Unal S, Arslan S. Intraarticular hyaluronic acid injection for the treatment of reducing and nonreducing disc displacement of the temporomandibular joint. Ann Plast Sur. 2009;62(3):265-7.

30. Guarda-Nardini L, Oliviero F, Ramonda R, Ferronato G. Influence of intra-articular injections of sodium hyaluronate on clinical features and synovial fluid nitric oxide levels of temporomandibular osteoarthritis. Reumatismo. 2004;56(4):272-7. 